\title{
The State and Employment in Liberal Market Economies: Industrial Policy in the UK Pharmaceutical and Food Manufacturing Sectors
}

\section{Introduction}

Over the last two decades social scientists from various fields have shown great interest in issues of comparative political economy, in particular in examining the adjustment of national economies to processes of globalisation and intensifying international competition (Whitley 1999; Hall and Soskice 2001; Amable 2003). A key contribution of this research has been how it has demonstrated that economic activity continues to be largely influenced and shaped by the particular institutions, regulatory frameworks and cultures within individual and groups of countries.

The most high profile recent example in this vein is the literature adopting a varieties of capitalism framework. A central feature of this approach is the distinction it draws between two basic but contrasting types of economy, namely liberal market economies and coordinated market economies. It is argued that economic activity in liberal market economies such as the US and UK, is predominantly characterised by market transactions undertaken by atomistic firms. In contrast, varieties of capitalism authors highlight how in coordinated market economies such as Germany and Japan individual firms tend to be embedded into local, regional or sectoral networks, with non-market forms of economic regulation more prevalent (Hall and Soskice 2001).

The varieties of capitalism approach has both deepened understanding and generated critical debates and perspectives regarding the analysis of models of capitalism. Important perceived weaknesses of prevailing frameworks include the insufficient attention given to the role of the state in shaping economic and regulatory trajectories, and a failure to recognise the extent of heterogeneity existing within national economies (Crouch 2005; Howell 2007; Weiss 2010; Lane and Wood 2011).

The varieties of capitalism literature has been extensively referenced by employment scholars, with research from a varieties of capitalism perspective examining the impact of different institutional frameworks and governance regimes on employment outcomes, wage levels and skills (Estévez-Abe, Iversen and Soskice 2001; Doellgast, Holtgrewe and Deery 2009; Batt, Nohara and Kwon 2010).

The focus of this chapter is on addressing one of the key gaps in the varieties of capitalism literature, namely the inadequate attention given to the role of the state. We explore the impact of the state on employment in liberal market economies, with a particular focus on state industrial policy. Specifically, we examine the employment implications of state industrial policy in the UK pharmaceutical and food manufacturing sectors. In this way the chapter responds to calls for the connection of labour process research to 'a broader political economy' (Thompson 2003; Thompson and Vincent 2010).

We draw on secondary sources, including previous academic research; official statistics; government, state agency and industry body reports; periodicals and other news sources. This is supplemented with primary data consisting of interviews with policy makers, industry officials, senior managers and operational employees within the UK dairy processing and pharmaceutical sectors, undertaken in 2003-4 and 2008-2010 respectively. 
Our research identified substantial differences in state industrial policy towards the two sectors, which in turn underpinned divergent outcomes relating to employment, working conditions and skills. In pharmaceuticals a strategic and resource-intensive industrial policy on the part of government has enabled the UK sector to perform strongly and led to the creation of high quality jobs. In contrast, in food manufacturing the predominant reliance on market mechanisms has negatively impacted industry performance and resulted in poor job quality and deteriorating working conditions.

These findings illustrate the problematic nature of dominant paradigms and policy prescriptions regarding the role of the state in liberal market economies within the literature on comparative capitalism. In contrast, the positive potential impact of active state industrial policies on employment is emphasised. The chapter highlights the various ways in which governments in liberal market economies intervene in the economy and the important employment consequences of this, again challenging prevailing analytical frameworks.

The chapter first considers existing theory and research on the role of the state in liberal market economies. Next the definition and nature of state industrial policy is considered. The main findings regarding UK government industrial policy and its impact on employment in the pharmaceutical and food processing sectors are then presented. Finally, an analysis and conclusion is provided.

\section{The Role of the State in Liberal Market Economies}

\section{Dominant Conceptions}

In the varieties of capitalism framework, the primary function of the state in liberal market economies is seen to be to ensure the free operation of market forces, as this it is argued is the most effective method of coordinating firms and economic activity and hence enhancing economic welfare in such countries (Hall and Soskice 2001).

In his elaboration of national business systems, Whitley $(1999,2005)$ presents the 'arm'slength state' as a distinctive type of state approach to economic management and regulation, and notes how most so-called liberal market economies tend to be characterised by such an approach. He notes how arm's length states tend to concentrate on establishing and enforcing the framework and rules within which market transactions take place, while leaving the nature of economic activity and organisation within these frameworks to be largely freely determined by relevant economic and social actors.

Schmidt (2002) identifies 'market capitalism' as one of three main types of capitalism in Europe, while Amable's (2003) more wide-ranging study identifies 'market-based' systems as a distinct model. For these and the above authors, countries such as the US and UK that are conventionally described as liberal market economies, are distinctive because of their emphasis on competitive markets as the central drivers of growth and the predominantly hands-off role of the state in economic management.

\section{Theoretical and Empirical Critique}

Although typically presented as ideal types, these dominant conceptions of the role of the state in so-called liberal market economies are properly subject to both theoretical and empirical critique. In this regard, authors adopting a 'regulation approach' highlight the pervasive influence of the state on the economic sphere (Boyer 1990; Jessop 2002). For Boyer (1990: 42), the state 'plays a definite role in the establishment, rise, and crisis of every regime of accumulation.' 
Following Polanyi, Block (1994) notes how even in market-dominated systems, the state strongly shapes economic activity. Rueschemeyer and Evans (1985: 45) observe how in idealized market models, 'collective goods' will be inadequately provided and 'negative externalities' not controlled, which calls for state action to address these problems. Moreover where markets are not operating perfectly, state intervention is needed to stimulate and discipline entrepreneurial behaviour.

While noting the dominance of 'liberal market capitalism', Clift and Woll (2012) highlight the inadequate consideration of the role of the state in the comparative literature. In developing theory on economic patriotism, they flag up the great expansion in state economic intervention since the 2008 financial crisis aimed at promoting economic growth and welfare at national, sub-national and sectoral levels. This has been evident in liberal market economies such as the US and UK as well as others countries, with renewed interest in particular in industrial policy (ibid.). Previous empirical work by both economic sociologists and political scientists demonstrates the validity of these observations regarding the role of the state in liberal market economies (O'Riain 2004; Weiss 2010).

From an employment relations and labour process perspective, the policy prescriptions for states in liberal market economies contained in the models of capitalism literature are highly problematic. The analysis of Hall and Soskice (2001) and colleagues leads to the conclusion that in liberal market economies the free operation of market forces should be accentuated as far as possible. In addition, governments in liberal market economies are seen to be advised to concentrate industry support measures on sectors characterised by 'radical innovation' (e.g. biotechnology) that are best supported by flexible institutional frameworks (Casper 2007).

However numerous researchers have identified how deregulated, market-based systems create undesirable employment outcomes, including high levels of wage inequality, work intensification and job insecurity; and often provide limited opportunities for career progression and skills development for many workers (e.g. Finegold and Soskice 1988; Burchell, Lapido and Wilkinson 2002; Beynon et al. 2002; Green 2006).

Employment researchers are therefore interested in the scope for alternative approaches to economic management in liberal market economies to underpin more desirable employment outcomes, across a range of sectors. Following the discussion above, the potential of an active state industrial policy is currently of particular relevance (Hannon et al. 2011). We next consider the definition and forms of industrial policy.

\section{Defining and Identifying State Industrial Policy}

Following Johnson (1984: 8), we define industrial policy as concerned with 'the initiation and co-ordination of governmental initiatives to leverage upward the productivity and competitiveness of the whole economy and of particular industries in it.' The question of which policy mechanisms come within the realm of industrial policy is much debated (Coates 1996). We can nevertheless draw on the work of Block (2008) and others in identifying key state activities in this regard.

Block (2008) outlines four key ways in which states endeavour to pursue technology policy objectives. States engage in targeted resourcing, which involves identifying particular technological problems or areas of potential economic importance, and providing financial 
resources to support firms and other institutions in working on these. Second, states can engage in opening windows, which Block (2008: 172-173) explains involves governments supporting more bottom-up, less targeted innovation by providing funding and other support to many different projects and institutions.

Third, states engage in technological and business brokering. The former involves connecting different actors or groups so that they can take advantage of each other's knowledge. Business brokering includes helping technologists attempting to commercialise a product obtain the required funding, make necessary business connections and identify potential customers. Finally, facilitation encompasses a wide range of activities such as creating appropriate regulatory frameworks for new products or ensuring suitable physical infrastructure is in place.

Other key industrial policy activities identified in the literature include the creation of financial incentives, for example in the form of taxation rates or R\&D tax credits; attraction of foreign direct investment; developing capabilities (for example general research capabilities or workforce education and training); and public procurement (Porter 1990; Huggins and Izushi 2007; Weiss 2010). These various concepts can be used to evaluate state industrial policy in specific sectors. We now consider the role of state industrial policy in the UK pharmaceutical sector.

\section{Industrial Policy and the UK Pharmaceutical sector}

Pharmaceuticals is a sector in which the role and importance of industrial policy is very apparent. In developing new products, pharmaceutical firms need to draw on research conducted by universities and research institutes, and they also rely on these actors to supply them with an educated workforce (Van Egeraat and Barry 2008). Similarly, they require close relationships with health sector organisations in order to test the clinical utility of new products as well as find buyers for them. In addition, given the extremely expensive nature of new product development in the sector, any financial incentives that governments or other actors can provide are much sought after (ibid; Thomas 1994).

Various aspects of the industrial policy context historically promoted the development of the UK pharmaceutical sector, including demanding product safety requirements imposed by national regulatory agencies; the development and expansion of the National Health Service; the favourable rules of the UK's pricing system for pharmaceutical products; the very strong public science base; and the government's strategic attraction of foreign direct investment of an innovative nature (Thomas 1994; Lane and Probert 2003; Slinn 2005). Although not without its critics (Froud et al. 1998), pharmaceuticals is frequently highlighted as one of the success stories of the British economy, while a strong biotech/biopharma industry has also been developed (Lawton-Smith and Bagchi-Sen 2006).

Over the last 10-12 years industrial policy towards the sector has become progressively more active. The Labour government established the Pharmaceutical Industry Competitive Taskforce in 2000 to examine the competitive position of the industry (PICTF 2001). This led to the establishment of the Ministerial Industry Strategy Group, which has since met twice a year, bringing together industry and government representatives to discuss key issues affecting the sector.

The Office for Life Sciences was set up in January 2009 as a cross departmental body with the task of promoting the competitiveness of the UK life sciences sector. Various working 
groups comprising representatives from government, industry and academia were formed, which led to the development of an overarching 'blueprint' document in 2009 and subsequent progress report in early 2010 (OLS 2009, 2010).

The policies of the Conservative-Liberal government have built closely on those of its predecessor. Pharmaceuticals and biopharmaceuticals are seen, within the context of the wider life sciences sector, as being industries of great strategic importance, and they benefit from very substantial and hands-on support. The government presented its Strategy for UK Life Sciences in December 2011 (BIS/OLS 2011). This outlined thirty one specific actions to be implemented, with progress and additional initiatives outlined in a report published in December 2012 (HM Government 2012a).

The various actions and initiatives include examples of each of the ways in which states may act in the industrial policy sphere outlined above. A high profile example of Block's (2008) 'targeted resourcing' and 'opening windows' categories is the Biomedical Catalyst Programme. Funded to a total of $£ 180$ million over three years and managed by the Medical Research Council and the Technology Strategy Board, this involves the provision of grants to small and medium enterprises and universities to develop innovative solutions to particular biomedical challenges. Support is provided for feasibility, early and late stage projects. By the end of 2012, £49 million had been committed to 64 projects, with an additional $£ 25$ million of private sector funds leveraged from this (HM Government 2012a: 9).

An important government objective announced in 2012 is to enable UK institutions and businesses to tap into the enormous therapeutic and commercial potential of genomic research. The government has outlined measures aimed at combining the UK's existing strengths in genome research with the National Health Service's status as a world-leading and data rich healthcare system, to create a framework from which innovative genome related products, technologies and services may be developed (HM Government 2012a). The Department of Health is to invest $£ 100$ million to fund the sequencing of 100,000 whole genomes, support the linking of data and treatment options, and aid the development of related skills. Additional funding will be provided by the Medical Research Council and the Technology Strategy Board (ibid: 45-47).

In addition to opening windows, this is arguably an example of 'facilitation' (Block 2008). In this example as well as throughout the life sciences strategy as a whole, there is a strong emphasis on harnessing the National Health Service's role as procurer and user of medicines and treatments to the advantage of both industry and patients. The initiatives listed also involve the government and its related agencies in 'brokering' activities (Block 2008). A notable feature is the support for collaborative projects between firms, universities and National Health Service institutions.

The creation of financial incentives is also clearly evident. In direct response to lobbying and policy critique on the part of the life science sector, the Conservative-Liberal government introduced a 'patent box' system from April 2013. This applies a lower tax rate $(10 \%)$ to profits from patents developed and commercialised in the UK, with the expectation that this will create incentives for firms to develop and commercialise products in the country. This measure sits alongside the progressive reduction of corporation tax from $26 \%$ to $20 \%$ and ongoing refinements to the $R \& D$ tax credit scheme. 
The attraction of foreign-direct investment is an important focus, with the government agency UK Trade \& Investment having developed a specially tailored life sciences marketing and promotion campaign. From August 2012 this has been the responsibility of a dedicated unit within UK Trade \& Investment, the Life Sciences Investment Organisation.

A number of the measures outlined above can be said to 'develop capabilities.' Other initiatives in this regard relate to skills and training. The Strategy for UK Life Sciences outlined the objective of increasing the number of apprenticeships and industry placements being taken up in the life sciences sector. Cogent, the state-funded Sector Skills Council for process industries, introduced a Higher Level Apprenticeships in Life Sciences in 2012, as well as a Technical Apprenticeship Service that supports employers in the recruitment, selection and training of apprentices (HM Government 2012a: 53).

\section{Performance and Employment Outcomes}

As outlined above, the industrial policy context historically promoted the development of the UK pharmaceutical sector. Alongside increasing demand for pharmaceutical products underpinned by rising levels of economic welfare and the expansion of national health systems, this supported sustained levels of high growth in the UK sector from the 1950s to the 1980s (Froud et al. 1998; Slinn 2005). The number of R\&D professionals employed expanded significantly during the $1950 \mathrm{~s}$, while total employment in the sector increased from 60,000 in 1963 to 80,000 in 1992 (Froud et al. 1998: 562; Slinn 2005: 182).

Over the last two decades the world pharmaceutical sector has been characterised by enormous turbulence. In the 1980s incumbent firms came under increasing pressure due to a decline in the rate of successful new drug development; shorter effective patent life due to lengthier development and approval processes; downward pressure on margins exerted by cost-conscious national governments; and increased competition from manufacturers of generic drugs (Froud et al. 1998; Van Egeraat and Barry 2008). These pressures prompted very significant rationalization within the UK industry from the early 1990s, involving various acquisitions and mergers between firms as well as cost-cutting within individual businesses (Froud et al. 1998).

This process of change and rationalization is ongoing. Outsourcing activities such as the conduct of molecule screening or later stage clinical research has become commonplace, while there is a move among the leading firms to target investments in fundamental research to emerging countries such as China and India (Ernst and Young 2010). In addition, the progressive development of the medical biotechnology sector has challenged existing firms and operating models. This has led to a shift in innovation to small firms and greater collaboration between them and the larger incumbents (ibid).

The employment consequences of these processes have been evident in the UK in recent years. The US multinational Pfizer closed its flagship R\&D facility at Sandwich in Kent in 2011 with the loss of 1,800 jobs, although this was partially offset by an expansion of the company's Cambridge research centre. AstraZeneca, a leading Anglo-Swedish firm, announced the closure of its principal UK R\&D site in Cheshire in March 2013 with the loss of 550 jobs, having previously undertaken substantial job cuts in 2010 and 2012. AstraZeneca's R\&D activity is now to be located in Cambridge, where a new facility employing 1,600 scientists will be opened. The extent of the reduction in R\&D jobs at these and other larger firms is reflected by the fact that the Royal Society of Chemistry estimated 
there to have been a $20 \%$ drop in the number of its members doing pharmaceutical research since 2008 (RSC 2011).

Recent trends and those in R\&D in particular, are seen by industry officials and company managers to be primarily due to competitive trends in the pharmaceutical sector as opposed to deficiencies in the UK policy context (House of Commons Science and Technology Select Committee 2011; HM Government 2012a). Some critics disagree, arguing that despite the various initiatives the UK government does not invest sufficiently in science and technology, with MNCs preferring to invest in countries such as the US and China where investment is far greater (Mazzucato 2011). In manufacturing the UK has lost jobs to countries such as Singapore and Ireland that offered more attractive financial incentives for investment. Jobs have similarly been lost in clinical trial related activities due to perceived weaknesses in relevant policies and processes (Whitehead 2013). A major perceived weakness is the persistently low adoption by the NHS of new medicines, with the Association of the British Pharmaceutical Industry highlighting this as a serious impediment to innovation and investment (ABPI 2013).

While the latter constitute perceived weaknesses and negative effects of the UK policy context, other recent announcements reflect efforts to improve the policy framework for the sector. In March 2012, in direct response to the government's decision to introduce the patent box system and reduce corporation tax, the British company GlaxoSmithKline announced a $£ 500$ million investment in UK manufacturing, which is expected to lead to the creation of 1,000 jobs. Notably this includes the opening of a new biopharmaceutical manufacturing facility. In partnership with the government, other public agencies and the Wellcome Trust, GSK has also invested in an open innovation bioscience campus with potential to house 1500 scientists.

Other positive developments in the last few years include the US multinational Lilly opening a new neuroscience R\&D facility supporting the work of 130 scientists, and the establishment by three other pharma MNCs, Astellas, Eisai and Quintiles, of European headquarters in the UK. Lilly's management expressly highlighted the UK's world class reputation in neuroscience as central to that firm's new development, with representatives from the other firms also mentioning the advantages of UK government policy and the broader environmental context. As noted above, Pfizer has expanded its existing R\&D centre at Cambridge, while AstraZeneca is to open a new facility there. AstraZeneca's CEO identified the UK government's support for life sciences and the very strong biomedical cluster in Cambridge as key reasons behind the latter decision.

Officials from the Bioindustry Association, which represents biomedical firms, note that the government's Biomedical Catalyst, patent box and corporation tax initiatives have significantly strengthened investment and business confidence in that sector (BIA 2013). They nevertheless continue to call for additional investment support (ibid).

Despite fluctuations, overall pharmaceutical employment remained largely stable between 1995 and 2010 (ABPI 2011). A recent government report outlines that there are approximately 96,000 people working in pharmaceuticals and medical biotechnology in the UK (HM Government 2012b). Employment in the former decreased by 10\% between 2011 and 2012, reflecting the ongoing rationalization at the larger firms outlined above. In contrast numbers in medical biotechnology increased slightly, by $0.3 \%$. 
Turnover in UK pharmaceuticals and medical biotechnology in 2012 was approximately $£ 30$ billion and $£ 4$ billion respectively (ONS 2012a). The pharmaceutical sector invested $£ 5$ billion in Business R\&D in 2011, which represented 28\% of total UK investment, and has a positive trade balance of almost $£ 7$ billion (ONS 2012b; BIS 2012: 47). Provisional data from the Annual Survey of Hours and Earnings show that in 2012 the median gross hourly wage in pharmaceuticals was $£ 16.20$, compared with $£ 12.15$ for manufacturing as a whole and $£ 11.26$ for all UK employees. Cogent (2010: 11) estimates that 58\% of the pharmaceuticals workforce is educated to National Vocational Qualification level 4 or above (i.e. degree level or above), compared with under $32 \%$ for the labour force as a whole.

\section{Industrial Policy and the UK Food Processing Industry}

The UK food manufacturing industry historically developed largely incrementally and autonomously. Small, family owned businesses that supplied local or regional markets were commonplace, in particular in traditional food sectors such as bread, meat and dairy (Burns 1983; Smith, Child and Rowlinson 1990). In contrast, newer products and activities such as chocolate manufacture that were marketed and advertised nationally, lent themselves more readily to increased scale and the use of mass production technologies (Smith et al. 1990).

While state industrial policy was not central, government action and policies were nevertheless important in facilitating the development of the sector, for example by regulating the marketing and safety of food products (Burns 1983; Burden 1996; French and Phillips 2000). As with pharmaceuticals, the ability of food manufacturers to draw on the research capabilities of UK universities, has historically aided innovation in the sector (Armstrong 2003). The government's limited regulation of monopolies and mergers within the industry as well as market share in food retailing, was seen to underpin the dramatic concentration that took place from the 1960s (Burns 1983; Smith et al. 1990).

One area of the food industry in which government action was historically more prominent is dairy processing. From the 1930s until 1994, Milk Marketing Boards established by government operated as monopoly purchasers of raw milk across the UK, setting the farm gate price of milk for both the liquid and manufacturing sectors using a system of 'end-use pricing' (Banks 2000). The system also provided dairy processors with fixed and typically high margins for the production of specified products.

Central objectives of this regulatory framework were to secure a high milk price for farmers and to promote the development of dairy processing. Important public good structures were established, notably a collaborative research and development programme and shared-use pilot plant facilities (Armstrong 2003). However the Conservative government deregulated the dairy industry in 1994, which led to the break up of this system and related institutions (ibid.).

Since the 1990s, UK government policy relating to dairy and other sub-sectors of the food industry has placed a strong emphasis on promoting competition and efficiency, with progressively more attention also devoted to achieving environmentally friendly, sustainable production that underpins healthy consumption patterns (DEFRA 2002a and b; Cabinet Office 2008; HM Government 2010).

The New Labour governments did not see food manufacturing as a strategic industry from an industrial policy perspective. The Conservative-Liberal government is developing a strategy for the 'agri-tech' sector aimed at harnessing the UK's strengths in agricultural science and 
technology to develop products and technologies promoting efficient and sustainable production (BIS 2012). The focus here appears predominantly on agriculture, which food industry representatives have challenged (All-Party Parliamentary Food and Drink Manufacturing Group 2012).

The government and related agencies have nevertheless adopted a range of measures relevant to food manufacturing in recent years. The Technology Strategy Board opened a Food Processing and Manufacturing Efficiency competition, funded by the Technology Strategy Board, the Department for the Environment, Food and Rural Affairs and two research councils. This focused on encouraging more efficient processing, packaging and distribution, and the recycling of by-products and waste; with successful projects granted up to $50 \%$ public funding (from $£ 100 \mathrm{k}$ to $£ 2.5 \mathrm{~m}$ ). In December 2012, £11 million was awarded for 32 collaborative research projects involving businesses and academic or research institutions.

The Technology Strategy Board also operates a Nutrition for Life competition, which supports new product development aimed at developing healthier, safer and more nutritious food. In 2011, £6.5 million was awarded for 27 major collaborative projects focused on the development of innovative technologies or processes. In addition, 24 small and medium enterprises were supported in carrying out small-scale technical feasibility studies (obtaining up to $£ 25,000$ each). Food manufacturing firms can also apply for funding under the TSB's High Value Manufacturing competition.

While total public expenditure on agriculture and food research is substantial (for example totalling $£ 415$ million in 2008/9), the emphasis tends to be on agricultural or more fundamental food research as opposed to 'near market' research that would be of potential application by processing firms.

In January 2012 DEFRA published a Plan of Action on Driving Export Growth in the Farming, Food and Drink Sector (DEFRA 2012a). This was drawn up together with UK Trade \& Investment and representatives from four trade associations. The development of specific action points was overseen by the Agri-food and Drink Exports Forum, comprising top exporting companies and co-chaired by the Minister of State for Farming and Food and the CEO of Nestlé UK.

The Action Plan identified the potential of food and drink exports to drive growth in the agrifood sector and in that way contribute to the wider development of the UK economy. Relevant activities and initiatives announced included the holding of regional events to encourage companies to export; making export paperwork simpler and easier for companies to access; and financially supporting inexperienced companies to showcase their products at international trade shows (ibid). Government ministers have committed to promoting British produce abroad.

The Conservative-Liberal government is also taking action intended to better regulate processor-retailer relationships. The Groceries Code Adjudicator Bill 2012-13 is currently going through parliament and when implemented will establish an adjudicator to monitor and enforce the Groceries Supply Code of Practice, which applies to large retailers. The intention is to better protect farmers and food processors in their dealings with the latter.

Finally, food manufacturing firms are drawing on the government's funding of apprenticeship training, which amounted to $£ 1.5$ billion for 2012-13. The Food and Drink 
Federation announced a target of doubling the number of apprentices in the sector between August 2011 and December 2012. This was more than achieved, with the number of apprentices increasing from 1,700 to 4,700 (FDF 2012a). The industry was assisted in this process by two publicly funded organisations, the National Apprenticeship Service and the National Skills Academy for Food and Drink (ibid.).

\section{Performance and Employment Outcomes}

Historically food and drink manufacturing has been an area of strength for the UK economy. While US multinationals assumed powerful positions in the industry, British-owned firms remained dominant into the 1980s (Smith et al. 1990). As outlined earlier, the sector witnessed very substantial concentration from the 1960s, with industry structures becoming rather oligopolistic. Food retailers became more powerful during the 1970s, prompting further rationalization within the industry (ibid.).

The position of retailers has become even stronger over recent decades and combined with a relative decline in consumer expenditure on food and an increase in imports, this placed substantial downward pressure on turnover levels within the UK industry (James and Lloyd 2008: 212). As a consequence the UK fell behind Germany and France to become the thirdlargest food manufacturer in Europe (ibid.).

In the dairy sector, deregulation by the Conservative government in 1994 led to enormous turbulence. Combined with a short-term financial orientation characteristic of many larger British firms, the difficult competitive conditions prompted a number of indigenous companies to curtail investment in new product development and exit the industry. A consequence of this was a significantly reduced presence on the part of indigenous firms in higher value activities such as the manufacture of yoghurt and desserts, which instead became dominated by foreign MNCs (Hannon 2005). While working conditions at the latter are potentially highly desirable, in the lower value, commodity-type markets for milk and cheese, low pay, work intensification and a lack of training and development are commonplace (Hannon 2005, 2010).

Case study research on other food sectors has similarly identified a notable deterioration of working conditions in recent years, with wages in relative decline, benefits being cut back and work intensified (James and Lloyd 2008, Edwards et al. 2009; Newsome et al. 2009; Hopkins 2012). In addition, food processing employers are making greater use of flexible labour practices and many are reliant on migrant workers to fill positions. The flexible and light-touch regulatory framework and the emphasis on the free operation of market forces on the part of the UK government, are seen to underpin these outcomes (James and Lloyd 2008, Edwards et al. 2009; Newsome et al. 2009). While job quality has in general therefore deteriorated, there is significant heterogeneity within the industry. Working conditions at large branded manufacturers and some foreign-owned MNCs operating in commodity type sectors can be comparatively good (FDF 2012b; Hannon 2005, 2010).

The food manufacturing sector has nevertheless performed quite strongly over the last few years, with a 9\% increase in industry turnover between 2008 and 2011 (ONS 2012a). Notably, food and drink continues to be the UK's largest manufacturing sector by both turnover and employment, with turnover of $£ 72$ billion in 2011 (ibid.). Exports of agri-food products have also grown rapidly since 2005 (Defra 2012; FDF 2012). The UK still however has a very large trade deficit in food, feed and drink of $£ 18.6$ billion (Defra 2012: 37). The 
food manufacturing sector invested $£ 350$ million in business R\&D in 2011 , which accounted for two percent of total UK expenditure (ONS 2012b).

Industry officials have highlighted and acknowledged the recent support provided to the sector by the UK government and state agencies (FDF 2012). At the same time, they identify various areas for improvement and express the view that in comparison with other sectors, food manufacturing has received relatively little industrial policy assistance (The Engineer, May 9, 2011).

The Director General of the Food and Drink Federation has stated that the industry does not receive the support needed to undertake the radical innovation required to stay ahead of international competition, highlighting a lack of funding for applied research. She has called for a strategy to be developed for the sector and for government to work with the industry to assess objectives for $R \& D$ and innovation and allocate funding to these (All-Party Parliamentary Food and Drink Manufacturing Group 2012).

Total employment in UK food manufacturing fell from 510,000 in 1998 to 381,000 in 2010, reflecting continual rationalization in the sector. Provisional data from the Annual Survey of Hours and Earnings show that in 2012 the median gross hourly wage for the manufacture of food products was £9.17. This compares unfavourably with the figures for the wider manufacturing sector outlined earlier. James and Lloyd (2008: 217) note how one third of process operatives in the sector are paid below the low-pay threshold, with the dominance of low-skill jobs reflected by the fact that over half of the sector workforce does not possess the equivalent of a school-leaving qualification (ibid.).

\section{Analysis and Conclusion}

The research undertaken identified important differences in employment outcomes between the pharmaceutical and food manufacturing sectors. In pharmaceuticals there has and continues to be substantial change in the composition of employment, with high profile recent job losses at larger firms. However total numbers across the sector as a whole remain comparatively stable, with jobs being highly skilled and paid. In contrast, numbers employed in food manufacturing have fallen substantially, with a notable deterioration in working conditions and job quality in evidence in recent years.

While wider sectoral characteristics and trends are key, the research findings highlight the importance of state economic policy in influencing processes and outcomes within both sectors. The government has historically played a central role in shaping the development of the UK pharmaceutical sector, with a plethora of measures and initiatives involving very sizable financial resources in evidence in recent years. Although subject to criticism, these measures have helped UK pharmaceutical companies maintain a strong competitive position as well as enter new markets and activities. This in turn has supported employment and job quality in the sector.

In contrast, food manufacturing in the UK historically developed more autonomously and government policy towards that sector has prioritised the free operation of market forces, albeit with some recent signs of a more active approach. While relevant indicators reflect promising performance over the last few years, UK food manufacturers continue to lag behind their foreign counterparts in terms of innovation and presence in higher value market segments. The intense competitive environment and flexible regulatory framework has led to 
extensive rationalisation of employment and causes many of the remaining jobs in the sector to be characterised by low wage and skill levels and work intensification.

These findings highlight the problematic nature of dominant paradigms and policy prescriptions regarding the role of the state in liberal market economies within the literature on comparative capitalism. The evidence from food manufacturing demonstrates the negative consequences for employment and working conditions of the predominant reliance on market forces to regulate and promote economic activity in liberal market economies, envisaged by Hall and Soskice (2001) and colleagues. The findings from food also challenge the suggestion that governments in liberal market economies should focus economic support on certain sectors to the exclusion of others (Casper 2007).

In contrast, the evidence from pharmaceuticals points to the potential for and positive employment effects of an active state industrial policy, even in liberal market economy contexts (Hannon et al. 2011). The identification of state industrial policy as a key determinant of competitive and employment outcomes is particularly pertinent at the current time, as the credit crunch and recession have prompted an increase in state intervention in the economic sphere (ibid; Clift and Woll 2012). In this regard, the chapter responds to Thompson and Vincent's (2010) call for more research on the 'connective tissue' between the labour process and the broader political economy.

Our findings and analysis support the work of authors who have criticised prevailing conceptions of the role of the state in liberal market economies (Block 2008; Weiss 2010; Clift and Woll 2012). While the UK is commonly identified as a country in which the state focuses primarily on ensuring the free operation of market forces, the reality is more nuanced. The evidence from pharmaceuticals in particular provided detailed examples of the various general ways in which governments can intervene from an industrial policy perspective, contrary to dominant conceptions regarding the role of the state in liberal market economies (Hall and Soskice 2001; Block 2008; Weiss 2010).

\section{Acknowledgements}

The primary research for this chapter was supported by two research awards from the Economic and Social Research Council (R42200034459 and RES-062-23-1183). Thanks to the editors for very helpful comments on earlier drafts. 


\section{References}

ABPI (2011) Knowledge Hub web pages, London: Association of the British Pharmaceutical Industry (www.abpi.org.uk).

ABPI (2013) 'ABPI response to FT article on health of UK pharmaceutical industry', ABPI statement, April 26, London: Association of the British Pharmaceutical Industry (www.abpi.org.uk).

All-Party Parliamentary Food and Drink Manufacturing Group (2012) Meeting notes from Innovation Round table, October 22, London: Food and Drink Federation (www.appgfooddrink.org.uk).

Amable, B (2003) The Diversity of Modern Capitalism, Oxford: Oxford University Press.

Armstrong, D. (ed.) (2003) The History of the Society of Dairy Technology, Bicester: Society of Dairy Technology.

Banks, J. (2000) 'Reorganisation of Milk Marketing Arrangements in the United Kingdom, 1994-2000', pp. 379-405 in H. Schwarzweller and A. Davidson (eds.), Dairy Industry Restructuring, Oxford: Elsevier.

Batt, R., Nohara, H. and Kwon, H. (2010) 'Employer Strategies and Wages in New Service Activities: A Comparison of Co-ordinated and Liberal Market Economies', British Journal of Industrial Relations, 48(2): 400-435.

Beynon, H., Grimshaw, D., Rubery, J. and Ward, K. (2002) Managing Employment Change: The New Realities of Work, Oxford: Oxford University Press.

BIA (2013) 'Growing UK biotech sector discusses growth and jobs in Westminster; BIA taking the bioscience sector to Parliament', Press Release, London: Bioindustry Association, January 31 (www.bia.org.uk).

BIGT (2009) The Review and Refresh of Bioscience 2015: A Report to Government by the Bioscience Innovation and Growth Team, London: Department for Business, Enterprise and Regulatory Reform.

BIS (2010) A Strategy for Sustainable Growth. London: Department for Business, Innovation and Skills.

BIS (2012) 'Industrial Strategy: UK Sector Analysis', BIS Economics Paper No. 18, London: Department for Business, Innovation and Skills.

BIS/OLS (2011) Strategy for UK Life Sciences, London: Department for Business, Innovation and Skills.

Block, F. (1994) 'The Roles of the State in the Economy', pp. 691-710 in N. Smelser and R. Swedberg (eds.), The Handbook of Economic Sociology, Princeton: Princeton University Press.

Block, F. (2008) 'Swimming against the Current: The Rise of a Hidden Developmental State in the United States', Politics \& Society, 36(2): 169-206.

Boyer, R. (1990): The Regulation School: A Critical Introduction, New York: Columbia University Press.

Brinkley, I. (2008) The Knowledge Economy:? The Economic Life of Nations, London: The Work Foundation.

Burchell, B., Lapido, D. and Wilkinson, F. (2002) Job Insecurity and Work Intensification, London: Routledge.

Burden, T. (1996) 'Agriculture', pp. 112-134 in D. Coates (ed.), Industrial Policy in Britain, Basingstoke: Macmillan.

Burns, J. (1983) 'A Synoptic View of the Food Industry', in J. Burns, J. McInerney and A. Swinbank (eds.), The Food Industry, London: Heinemann. 
Cabinet Office (2008) Food Matters: Towards a Strategy for the 21st Century, London: The Cabinet Office Strategy Unit.

Casper, S. (2007): Creating Silicon Valley in Europe: Public Policy towards New Technology Industries, Oxford: Oxford University Press.

Clift, B. and Woll, C. (2012) 'Economic patriotism: reinventing control over open markets', European Journal of European Public Policy, 19(3): 307-23.

Cogent (2010) UK Sector Skills Assessment 2011, Warrington: Cogent (www.cogent-ssc.com)

Crouch, C. (2005) Capitalist diversity and change: recombinant governance and institutional entrepreneurs. Oxford: Oxford University Press.

Defra (2002a) Strategy for Sustainable Farming and Food - Facing the Future, London: Department for Environment, Food and Rural Affairs.

Defra (2002b) Response to the Report of the Policy Commission on the Future of Farming and Food by HM Government, Cm 5709, London: Department for Environment, Food and Rural Affairs.

Defra (2012a) Driving Export Growth in the Farming, Food and Drink Sector: a plan of action, London: Department for Environment, Food and Rural Affairs.

Defra (2012b) Food Statistics Pocketbook 2012, London: Department for Environment, Food and Rural Affairs.

Dench, S., Hillage, J., Reilly, P. and Kodz, J. (2000) 'Employers Skill Survey: Case Study Food Manufacturing Sector', Skills Task Force Research Paper, no. 34, Sheffield: Department for Education and Employment.

Doellgast, V., Holtgrewe, U. and Deery, S. (2009) 'The Effects of National Institutions and Collective Bargaining Arrangements on Job Quality in Front-Line Service Workplaces', Industrial \& Labor Relations Review 62(4): 489-509.

Egeraat, C. van and Barry, F. (2008) 'The Irish Pharmaceutical Industry Over the Boom Period and Beyond', National Institute for Regional and Spatial Analysis Working Paper Series, No. 39, Maynooth: National University of Ireland, Maynooth.

Ernst and Young (2010) Beyond Borders: Global Biotechnology Report 2010. Ernst and Young (www.ey.com)

Estévez-Abe, M, Iversen, T. and Soskice, D. (2001) 'Social Protection and the Formation of Skills: A Reinterpretation of the Welfare State', pp. 145-83 in P. Hall and D. Soskice (eds.), Varieties of Capitalism: The Institutional Foundations of Comparative Advantage, Oxford: Oxford University Press.

FDF (2012a) 20/20 Vision For Growth Achievements 2012, London: Food and Drink Federation.

FDF (2012b) Delivering Growth through Apprenticeships, London: Food and Drink Federation.

Finegold, D. and Soskice, D. (1988) 'The Failure of Training in Britain: Analysis and Prescription', Oxford Review of Economic Policy, 4(3):21-53.

French, M. and Phillips, J. (2000) Cheated not poisoned? Food regulation in the United Kingdom 1875-1938, Manchester: Manchester University Press.

Froud, J., Haslam, C., Johal, S., Williams, K. And Willis, R. (1998) 'British Pharmaceuticals: A Cautionary Tale', Economy and Society 27 (4): 554-584.

Green, F. (2006) Demanding Work: The Paradox of Job Quality in the Affluent Economy. Princeton: Princeton University Press.

Hall, P. and Soskice, D. (eds.) (2001) Varieties of Capitalism: the institutional foundations of comparative advantage. Oxford: Oxford University Press.

Hannon, E. (2005) 'Prospects for the Upskilling of General Workers in Britain: A Case Study Comparison of the English and Irish Dairy Processing Industries', unpublished PhD thesis, University of Warwick. 
Hannon, E. (2010) 'Employee-focused research in HRM: the case of dairy processing', International Journal of Human Resource Management, 21(6): 818-835.

Hannon, E., Monks, K., Conway, E., Kelly, G., Flood, P., Truss, K. and Mastroeni, M. (2011) 'The state and industrial policy in Ireland: a case study of the Irish pharmaceutical sector', International Journal of Human Resource Management, 22(18): 3692-3710.

HM Government (2010) Food 2030, London: Department for Environment, Food and Rural Affairs.

HM Government (2012a) Strategy for UK Life Sciences: One Year On, London: Department for Business, Innovation and Skills.

HM Government (2012b) Strength and Opportunity 2012: the landscape of the medical technology, medical biotechnology, industrial biotechnology and pharmaceutical sectors in the UK, London: Department for Business, Innovation and Skills.

Hopkins, B. (2012) 'Explaining Variations in Absence Rates; Temporary and Agency Workers in the Food Manufacturing Sector', Human Resource Management Journal.

House of Commons Science and Technology Select Committee (2011) Oral and Written Evidence: Pfizer's decision to close its research and development facility at Sandwich (www.publications.parliament.uk)

Howell, C. (2007) 'The British Variety of Capitalism: Institutional Change, Industrial Relations and British Politics', British Politics 2: 239-263.

Huggins, R. and Izushi, H. (2007) Competing for knowledge: creating, connecting and growing. London: Routledge.

James, S. and Lloyd, C. (2008) 'Supply Chain Pressures and Migrant Workers: Deteriorating Job Quality in the United Kingdom Food-Processing Industry', pp. 211-246 in C. Lloyd, G. Mason and K. Mayhew (eds.), Low-Wage Work in the United Kingdom. New York: Russell Sage Foundation.

Jessop, B. (2002) The Future of the Capitalist State, Cambridge: Polity Press.

Johnson, C. (ed.) (1984) The Industrial Policy Debate, San Francisco: ICS Press.

Lane, C. and Probert, J. (2003) 'Globalisation and its impact on Competitiveness: The Case of the British and German Pharmaceutical Industry', ESRC Centre for Business Research, Working Paper No. 262, Cambridge: University of Cambridge.

Lane, C. and Wood, G. (eds.) (2011) Capitalist Diversity and Diversity within Capitalism, London: Routledge.

Lawton-Smith, H. and Bagchi-Sen, S. (2006) 'University-industry interactions: the Case of the UK Biotech Industry', Industry and Innovation 13(4): 371-392.

Mazzucato, M. (2011) The Entrepreneurial State, London: Demos.

Newsome, K., Thompson, P. and Commander, J. (2009) 'The Forgotten Factories: Supermarket Suppliers and Dignity at Work in the Contemporary Economy', pp. 145161 in S. Bolton and M. Houlihan (eds.), Work Matters: critical reflections on contemporary work, Basingstoke: Palgrave Macmillan.

O'Riain, S. (2004) The Politics of High-Tech Growth: Developmental Network States in the Global Economy, Cambridge: Cambridge University Press.

OLS (2009) Life Sciences Blueprint, London: Office for Life Sciences.

OLS (2010) Life Sciences 2010: Delivering the Blueprint. London: Office for Life Sciences.

ONS (2012a) Annual Business Survey 2011 (Provisional Results), London: Office for National Statistics.

ONS (2012b) Statistical Bulletin: Business Enterprise Research and Development, 2011, London: Office for National Statistics.

PICTF (2001) Pharmaceutical Industry Competitive Task Force Final Report. London: Department of Health/Association of the British Pharmaceutical Industry, March.

Porter, M. (1990) The Competitive Advantage of Nations, London: Macmillan Press. 
RSC (2011) 'Government at half way house in its life sciences plan, says chemistry chief', Press Release, London: Royal Society of Chemistry (www.rsc.org).

Rueschmeyer, D. and Evans, P. (1985) 'The State and Economic Transformation: Towards an Analysis of the Conditions Underlying Effective Intervention', pp. 44-77 in P. Evans, D. Rueschmeyer and T. Skocpol (eds.), Bringing the State Back In, Cambridge: Cambridge University Press.

Slinn, J. (1995) 'Research and Development in the UK pharmaceutical industry from the nineteenth century to the 1960s', pp. 168-186 in R. Porter and M. Tiech (eds.), Drugs and Narcotics in History, Cambridge: Cambridge University Press.

Smith, C., Child, J. and Rowlinson, M. (1990) Reshaping Work: the Cadbury Experience, Cambridge: Cambridge University Press.

Thomas, L. (1994) 'Implicit Industrial Policy: the Triumph of Britain and the Failure of France in Global Pharmaceuticals', Industrial and Corporate Change 3 (2): 451-89.

Thompson, P. (2003) Disconnected capitalism: or why employers can't keep their side of the bargain. Work, Employment and Society, 17 (2). pp. 359-378.

Thompson, P. and Vincent, S. (2010) 'Labour Process Theory and Critical Realism', pp. 4769 in in P. Thompson and C. Smiths (eds.), Working Life: renewing labour process analysis, Basingstoke: Palgrave Macmillan.

Weiss, L. (2010) 'The State in the Economy: Neoliberal or Neoactivist?', pp 183-209 in G. Morgan, J.L. Campbell, C. Crouch, O.K. Pedersen and R. Whitley (eds.), The Oxford Handbook of Comparative Institutional Analysis. Oxford: Oxford University Press.

Whitehead, S. (2013) 'Championing a UK success story - making growth sustainable', Online Opinion Piece, London: ABPI, February 13 (www.abpi.org.uk).

Whitley, R. (1999) Divergent Capitalisms: The Social Structuring and Change of Business Systems. Oxford: Oxford University Press.

Whitley, R. (2005) 'How National are Business Systems? The Role of States and Complementary Institutions in Standardising Systems of Economic Co-ordination and Control at the National Level', pp. 190-231 in G. Morgan, R. Whitley and G. Moen (eds.), Changing Capitalisms? Internationalization, Institutional Change and Systems of Economic Organisation, Oxford: Oxford University Press. 